\title{
Grundtvigs sysler og interesser i første halvdel af $183^{1}$
}

\author{
Af Helge Toldberg
}

Kaj Thaning har i sin skelsættende disputats $\left.{ }^{1}\right)$ Menneske forst Grundtvigs opgor med sig selv ( 1963 ) med stor styrke hævdet $183^{2}$ som det afgørende vendepunkt i Grundtvigs liv og forfatterskab, og også for en litteraturvidenskabelig betragtning ligger det herefter fast at 1832 er et af de største mærkeår ${ }^{2}$ ). Det er lykkedes Thaning at vise, at adskillelsen af det menneskelige og det kristelige, som proklameres i den lange indledning til Nordens Mythologi i 832, ikke bare overholdes i resten af forfatterskabet, men knytter de sidste 40 års litterære indsats til værkerne før krisen 1810; der kunne endda gives flere beviser herfor, skønt det ikke skorter på dem i det store værk. Kommende indsigelser må ventes at koncentrere sig om sagens anden side: om svælget mellem værkerne før og efter »den anden mageløse opdagelse« - I I. marts 1832 (jf. s. 520 ff.) - er så absolut og gennemgående som hævdet.

Redegørelsen for det $183^{2}$ opgivne standpunkt og dets spor $\mathrm{i}$ forfatterskabet har Thaning $\mathrm{i}$ det væsentlige samlet $\mathrm{i}$ sit indledningskapitel. For det længste tidsrum er den gjort så knap som muligt, men den bliver fyldigere jo nærmere man kommer 1832 , og der er et stort afsnit om »Udviklingen i i 83 I (s. 64-102 + noter). Kapiteloverskriften er dog lidt misvisende, idet det kun er tiden indtil den tredje Englandsrejse, som Gr. gav sig ud på 2/6 I 83 I, der afhandles

1) Af dagspressens anmeldelser skal især fremhæves Otto Paludans dobbeltkronik i Aarhuus Stiftstidendes 》strejftog《 I o. og I I. december 1963. En litteraturvidenskabelig anmeldelse af mig vil fremkomme i Danske Studier 1965 .

$\left.{ }^{2}\right)$ Herefter bliver de principielle litterære mærkeår I810, I815 og 1832. Gr.s første møde med Rimkrøniken og kladden til Et Blad af Fyllands Rimkrønike tilhører ganske vist 1814 , men frigivelsen af den nordiske mytologi til poetisk brug sker først 1815 med Thryms Kvide, og samme år stifter Gr. bekendtskab med Beowulf og lærer sig angelsaksisk, hvad der volder den største saglige omvæltning i hans norrøne studier. 
her; rejsen og de forberedende udkast til Nordens Mythologi fra efteråret indgår $\mathrm{i}$ hovedargumentationen $\mathrm{i}$ det følgende kapitel. Dispositionen er ellers rimelig nok, for det er vigtigt at få et indtryk af hvad Gr. var optaget af lige før hans nyorientering modnedes. Det er bare et spørgsmål om Thaning er kommet til bunds i dette.

Det velskrevne afsnit om Gr.s gøremål i de første fem måneder af I 83 I behandler i hovedsagen færdiggørelsen af Søndags-Bogen III, der udkom 2 I/7 I83 I, og den saglige belysning lægger klart op til skellet mellem Gr.s prædiken her og senere. Det ømme punkt er dateringen af arbejdets udførelse, hvor Thaning opnår en kulmination ved sin overbevisning om at de tre prædikener til skærtorsdag, langfredag og påskedag stammer fra selve påskeugen. Hans overvejelser støtter sig dels til prædikenernes karakter og forhold til eventuelle skrevne forlæg fra Gr.s præstegerning ved Vor Frelsers Kirke ${ }^{3}$ ), dels til Gr.s brevveksling med sine to nære venner Ingemann og Gunni Busck ${ }^{4}$ ); derimod har han i dette tilfælde ikke ænset datoen for censors trykketilladelse, $\mathrm{I} 6 / 3 \mathrm{I}_{3} \mathrm{I}^{5}$ ), hvis betydning vi skal komme tilbage til når vi har prøvet Thanings vurderingsgrundlag. Vi begynder med Gr.s konkrete oplysninger, der findes i breve til Busck, og citerer de to sidste fyldigere end Thaning (s. 79):

(20/12 1828, GBusck s. 70) Psalmerne bliver der vel neppe noget af for det Første, thi tredie Deel af mine Præken-Breve maa jeg nok see til at faae færdig, da der er adskillige vigtige Ting, jeg endnu ikke har skrevet reent ud af Posen om, og bør da nok giøre det, førend Foraaret rimeligviis giver mig andre Ærender at rygte, og Skoe at sye.

( ro/I I I830, GBusck s. 99, jf. Søndags-B III s. 25 ff.) Beskrivelsen af Elementerne $i$ en Prædiken om Verdens Undergang fandt jeg strax, da jeg kom hvor den var, og sender den, efter Aftale, til Giennemsyn. Ved selv at giennem-

3) Hvad der i nærværende undersøgelse oplyses herom, bygger enten på Thanings bog s. 68 ff. eller på den af ham foretagne registrering (i Registrant over N. F. S. Grundtvigs Papirer I, I957) af Grundtvig-arkiv fasc. I 8 og I9; kun i tilfælde af uenighed gives præcis henvisning.

4) Udgaverne, Grundtvig og Ingemann. Brevvexling I821-1859 (ved Svend Grundtvig, 1882) og Gunni Busck, et Levnedsløb $i$ en Prastegaard (ved Henr. Bech, 2. forøgede udg. 1878), betegnes i det følgende henholdsvis GrIng og GBusck.

5) At der står 1830 på titelbladet, er intet holdepunkt. Begge de foregående bind bar årstallet I 827, skønt det andet først udkom 3 I/Io I828, og det ville have stemt bedre med tidens skik at sætte 1828 på dem; man strakte jo gerne en bogs aktualitet ved at lade den se ud som nyudkommet et helt år. Årstallet 1830 tyder snarest på at forlaget har ventet fuldførelse sent i 1829, men tilretningen er i hvert fald sket for tidligt. 
see den, fandt jeg vel, at Anordningen ei længer var ganske efter mit Hoved, da Vinket til Slutning om den verdslige Sikkerhed, der er det tydeligste af alle Varslerne hidindtil, nu vist vilde været min Indledning, men dog fandt jeg Intet glemt af Hoved-Sagen.

(15. el. I6. febr. 1831, GBusck s. I 17) Skiøndt jeg har travlt med Søndagsbogen, som nu er givet under Trykken, men dog langt fra at være færdig, maa jeg strax takke Dig for Brevet, og om dets Indhold sige hvad jeg for Øieblikket kan.

(26/4 I83I, GBusck s. I33) Mine Prædiken-Studier vedblive at omkredse Troen og Daaben i større og mindre Cirkler, og naar jeg ogsaa har faaet dem for Lyset, vil vel Timen til at giøre et afgiørende Skridt i den virkelige Verden være kommet, ...

Disse meddelelser kan kun tolkes på én måde: Allerede $\mathrm{i}$ december I 828 er Gr. i gang med Søndags-Bogen III, og han betragter den som den opgave der skal løses først. Men da han i november i83o har lovet Busck at låne ham den anden af bogens prædikener, må han lede den frem; arbejdet har altså i længere tid været lagt på hylden. Ved midten af februar i 83 I er en del af trykmanuskriptet indleveret, men der er endnu noget uskrevet igen 26/4. Hvor meget oplyses ikke, men det tør sluttes at der er tiltænkt troen og dåben en fremskudt plads i det resterende.

Heroverfor står Thanings karakteristik ud fra indre kriterier, først og fremmest at Søndags-Bogen III modsat de to foregående bind er stærkt præget af »den kirkelige Anskuelse«, og dette forklarer han ved at den er udarbejdet jævnsides med og lige efter den store tidsskriftafhandling Skal den Lutherske Reformation virkelig fortscettes?, hvis tredje og sidste stykke Gr. fik færdigt 2 I/I I83 I (GrIng s. I I 2). I forbindelse med dette citerer Thaning (s. 64) fra Gr.s brev til Busck I5/I I83 I: »Alt hvad der enten i Munden eller i Pennen skal giøre aandeligt Gavn, maa være noget $N y t$, det Gamle duer ikke.« Denne udtalelse skulle man jo synes at turde bygge på, men den strider mod Gr.s egen praksis i Søndags-Bogen III, hvor han trykker den prædiken hvis anlæg han er nær ved at fortryde (jf. citatet her fra brevet Io/ I I I83o); og man må overveje om han ikke trods alt, for at prædikensamlingen skulle nå at blive færdig, har måttet indskrænke bevidst nyskabelse til den del han ikke allerede havde udarbejdet. Som hovedregel har Gr. nok under arbejdet fulgt kirkeåret, men det kan ikke udelukkes at enkelte prædikener er skrevet udenfor deres plads i rækken, hvis »noget Nyt« har gennemlynet ham, og siden er indsat på rette sted. Det er desuden en rimelig antagelse at Gr. har haft de 
første prædikener liggende fra tilløbet omkring julen I828, det store spørgsmål er om arbejdet derefter har hvilet i to år.

Thaning finder $\mathrm{i}$ bogen som helhed en skillelinje mellem bodskristendom, der præger de første prædikener og endnu tydeligere bevarede udkast til de tre første af dem - i fasc. 72 III $D$, skrevet med fjerpen, dvs. før 26/ I I I $830^{6}$ ) -, og sakramentkristendom, der er bærende $\mathrm{i}$ de senere. Bodskristendommen kendetegner ganske rigtigt $\mathrm{nr}$. I-5, men slår mærkeligt igennem igen i nr. I 7, pinseprædikenen (s. 392), mens sakramentkristendommen uddybes i nr. 20 og de fleste af de følgende. Når den er virkelig fremtrædende tidligere i bogen, skyldes det enten et polemisk sigte (i nr. I4-I 5, jf. ndf.) eller et naturligt udgangspunkt i dagens tekst (nr. 3, 9 og I I). Til tider er Thaning hildet af sin egen dogmatik og forvisning om en ubrudt linje frem mod gennembruddet $\mathrm{I}^{8} 3^{2}$, således når han ( $\mathrm{s.}$ 69) »dristigt《 tolker nytårsprædikenen (nr. 5) »som et forsvar mod det skjulte angreb på pilgrimskristendommen, som Grundtvig - uden at forstå rækkevidden af det - ikke kan undgå at føle knyttet til de Englandsindtryk, der sejrer $\mathrm{i}$ hans tankeverden året efter «, skønt Gr. ikke mæler et ord om England $\mathrm{i} \mathrm{den}{ }^{7}$ ). Thaning har slet ikke tænkt den tanke at nogle af prædikenerne kunne stamme fra de to foregående vintre, og den tidligere nævnte hypotese, at de tre påskeprædikener (nr. I I-I3) er blevet til i selve påskeugen $183 \mathrm{I}$, beror tilsyneladende kun på den stærke påskestemning i dem. Det er rigtigt at påskedagsprædikenen henviser til skærtorsdags, men den kan ikke være samtidig med langfredags. I påskedagsprædikenen lignes Lutherdommen ved Jesu nedfart til dødsriget, hvad der for Thaning beviser stor afstand fra helligtrekongerprædikenen, hvor Luthers komme lignes ved opstandelsen, men dette gælder også langfredags ${ }^{8}$ ). På den anden side knytter sidstnævnte,

6) Gr. omtaler i sit brev til Ingemann denne dag at han er gået over til at bruge stålpenne (GrIng s. I02). Som nyt dateringskriterium er det fremdraget Thaning s. 87. - Sammesteds fastslås, at trykmanuskript til Søndags-B III ikke kendes.

$\left.{ }^{7}\right)$ Udgangspunktet, 》Lad os giøre os et Navn«, og betragtningerne over dobbeltnavnet Jesus Christus hentyder til den kgl. anordning af $30 / 51828$, om at børn også skulle døbes med efternavn. Den drøftedes i breve mellem Busck og Gr. I I/3 og 10/4 I830 (GBusck s. 9 I ff.), og Gr. siger i det sidste: »Befalingen om Sammenblandelse af Døbe-Navne og Bi-Navne har nemlig lige fra Begyndelsen stødt min Følelse, og jeg kan endnu ikke ret betragte den uden som et nyt Aag lagt paa Disciplernes Halse, ... nen stammer fra april 1830 - eller vinteren $1828-29$.

$\left.{ }^{8}\right)$ Søndags-B III s. 29I: Men, kiære Venner! I som endnu lytte til Ordet om ham, der klarlig beviistes at være Guds Søn ved Opstandelsen fra de Døde: 
ligesom nr. 8, stærkt til nordisk mytologi, hvad man gerne med Thaning ser som et forvarsel om I832; men vi vil lade stå hen lidt endnu om nr. I 2 eller I 3 er ældst. Derimod må de begge af rent ydre grunde være skrevet før påsken $\mathrm{I} 83 \mathrm{I}$.

Bogen fik jo sit imprimatur I6/3 I83 I, og en væsentlig del må være sat inden da, selv om vi ved at Gr. endnu arbejdede på den 26/4. Efter anordningen påhvilede det kun censor at gennemse skrifter indtil 24 ark, fordi bøger af større omfang læstes meget lidt ${ }^{9}$ ); censuren skete normalt på grundlag af korrektur, helst sådan at arkene blev indleveret den ene dag og hentet den næste med censors påtegning. Trods overskridelse af de 24 ark ( $3^{8} 4$ sider) bærer både prædikensamlingerne og Nordens Mythologi I $83^{2}$ det daterede censurmærke, og det må antages at der i hvert enkelt tilfælde er indleveret mindst 25 ark, så censor kunne se at han i hvert fald var uden ansvar for resten $^{\mathbf{1 0}}$ ). Alle parter, også Gr. selv, må have ønsket at undgå en gentagelse af affæren i 1827 , da 3. stykke af tidsskriftartiklen $\mathrm{Om}$ Religions-Frihed blev undertrykt, efter at der var givet imprimatur alene på grundlag af de første ark; og i året efter Julirevolutionen måtte en ucensureret prædiken med overskriften Fanatismen betragtes som utilstedelig. Ud fra typografien i Søndags-Bogen III tør det sluttes, at 28 ark (s. I-448) har været forelagt ved censuren. Den eneste prædikenslutning ved arkgrænse findes nemlig s. 448, og det er tydeligt at satsen er strakt for at få 5 linjer til denne side; de tre foregående sider er afkortet til 29 linjer i st. f. de sædvanlige $30^{11}$ ), satsen står flere steder unaturligt spredt, og på s. 439 har Gr. måske selv hjulpet til med to linjers udvidelse i korrekturen efter et velmotiveret

ved hans aandelige Opstandelse i Morten Luther, som ved hans Legemlige fordum; I som vil trøste eder i Dødens Stund ved Livet og Uforkrænkeligheden, som han fra de Dødes Rige bragde for Lyset igien, og lader al Verden tilbyde ved sit Evangelium, som det evige Livs Ord!

9) Oplysningerne her bygger dels på en samtale med landsarkivar dr. Harald Jørgensen, dels på hans bog Trykkefrihedsspørgsmaalet i Danmark I799-1848 (I944) s. Io3 ff., samt Steen Johansens afhandling N.F. S. Grundtvig og censuren, Fund og Forskning IV (1957) s. $48 \mathrm{ff}$. , med en kronologisk liste over de censurerede skrifter.

10) Dog kan det tænkes at Søndags-B I, der modsat de to følgende bind har et forfatterforord, har fået imprimatur alene på grundlag af dette. Forordet er nemlig dateret $30 / 9$ I 827 , og censurdatoen er dagen efter, I/ I 0 .

11) I en nødssituation kunne satsen udvides til 3 I linjer, som s. 304 og 540 er nået op på. En tilsyneladende parallel til s. $44^{8}$ på s. $5^{1} 3$, med kun 4 linjer på siden og en linje kappet af hver af de 4 foregående, må skyldes en strygning i korrekturen af Gr. selv. 
punktum yderst $\mathrm{i}$ tredjesidste linje. 28 ark er vel også omtrent hvad et trykkeri med lidt umage kunne nå på en måned eller lidt over, og et par prædikener har nok kunnet afleveres efter at arbejdet var begyndt. Der er I 9 prædikener før s. 448, Io efter, og nr. I9 hører til 6. søndag efter trinitatis. Det er bemærkelsesværdigt, at udarbejdelsen af de fleste prædikener i første gruppe er sket med benyttelse af gammelt forlæg (i fasc. I8, ved nr. I4 i fasc. I9), men at dette $\mathrm{i}$ anden gruppe kun med sikkerhed gælder om nr. 20.

Det er allerede fastslået at den anden prædiken er ældre og fundet frem i november I830, men dette gælder vistnok også nr. I og 3-5, idet den aktivitet det førstanførte brev til Busck vidnede om, synes vedligeholdt indtil den sjette skulle skrives. Blandt de bevarede forarbejder til Søndags-B III i fasc. 72 III D ligger, som det sidste hvor der er brugt fjerpen (jf. note 6), et dobbeltblad med overskriften VI Leder, saa skal I finde og evangeliet til I. søndag efter helligtrekonger, men uafsluttet og uden udlægning; derimod bærer det lægnumerering (34) ligesom de yngste udkast til nr. I-3. Af nr. 4 og 5 kendes kun den trykte form, men ud fra Gr.s vane at gemme alle opgivne redaktioner af skrifter af enhver art, tør man regne med at de er trykt omtrent som de oprindeligt så ud. Af de følgende prædikener er nr. 7 og 8 repræsenteret (med stålpen), men så ingen før nr. I 7. På udkastet til denne findes lægnumereringen I02, og også nogle af de senere har lægnummer. At de pågældende papirer er udskudt af trykmanuskriptet, beviser et enkeltblad numereret $\mathrm{I}_{3} \mathrm{o}^{\mathbf{1 2}}$ ), hvis første ord falder sammen med Søndags-B III s. 496 næstsidste og sidste linje (Sagen til hvad der selv for Øieblikket knap er værd at nævne). Når læg med prædikenbegyndelse er unumereret, må det antages at en tidligere prædiken endnu ikke er lavet eller i det mindste er ufuldført; der er intet lægtal på nr. $8^{13}$ ) og to af de sidste prædikener (nr. 24 og 27 ). Derimod findes, med lægnummer I I 3 , begyndelsen til en opgivet men yderst veloplagt ${ }^{14}$ ) prædiken til 2. søndag efter trinitatis,

12) Fasc. 72 III D nr. I o, i Gr.-registrant bd. II fejlagtigt henført til Søndags-B III nr. 19. Den fælles tekst går til slutningen af næstsidste afsnit s. 499, hvor udkastet er noget vidtløftigere og nederst på siden standser midt i en sætning.

${ }^{13}$ ) Af nr. 7 findes kun en halv side et stykke inde i teksten.

14) Jf. følgende karakteristik af tidens sædvanlige prædiken, der er et åndshistorisk dokument: det er enten et Forsøg i Moralen eller Dogmatiken der oplæses, eller en Lovtale der holdes over Jordens skiønne Marker, og Øxen, Blomster og Kvinder, som Man vel maae græde over skal engang ombyttes med, Man veed ikke hvad paa hin Side Graven, men som Man dog giør klogest i at fryde sig ved, saalænge det kan vare. 
$X I X$ Den store Nadvere, mens den trykte nr. I9 er en tekst til 6. s. e. trin. Dette er et vidnesbyrd om at Gr. har haft god tid til at forberede nr. I9, og at den sandsynligvis først er afleveret til trykkeriet efter at man var begyndt at sætte.

Men at en lovende prædiken over evangeliet til 2. s. e. trin., som havde fået en epistelprædiken i Søndags-B I, er vraget til fordel for en knap så fængslende til en senere søndag, viser også noget andet. Hensigten med Søndags-Bogen var først og fremmest at Gr.s gamle menighed, der nu ikke mere kunne høre ham, skulle kunne læse tidssvarende prædikener af ham til alle søn- og helligdage, og han måtte derfor især være betænkt på dem der ikke var kommet med i de to første bind. Dette hensyn mærkes dog ikke meget i den første gruppe prædikener i Søndags-B III, dem der er sat inden censuren; før nr. I 9 er kun nr. 6, Io og I 2 til ny helligdage. I den anden gruppe er de det alle. I den samlede oversigt bagest i bogen mangler kun prædikener til søndag ml. jul og nytår, 2. søndag i fasten og 23. og senere søndage efter trinitatis, mens der til otte helligdage er en prædiken i hvert bind. Til denne stærke dækning bidrager i bd. III numrene I-2, 4-5, 8-9, I6 og I 8, spændende fra I. søndag i advent til trinitatis. Nogle af disse perikoper kan have meldt sig som selvfølgelige, og andre kan han have grebet til hvis det kneb med tiden; at nr. I8 hører til dem, er et næsten sikkert tegn på, at også den er afleveret til trykkeriet i februar. Læserkravet på fuldstændighed havde Gr. imidlertid tænkt på inden han tog fat. I fasc. 72 III A, blandet materiale til hele Søndags-Bogen, ligger et oktavdobbeltblad, utvivlsomt fra ${ }_{1} 8{ }_{2} 8^{15}$ ), på hvis første to sider alle årets helligdage er noteret, mens den tredje samler dem der ikke er med i bd. I-II. I denne liste er nogle helligdage, deriblandt 24. og 25. søndag efter trinitatis, som slet ikke kom med, mærket med et kryds, velsagtens tegn på at Gr. lå med et egnet forlæg. Mærkeligt nok er helligtrekongersdag helt glemt, skønt den i i 828 var faldet på en søndag og igen ville gøre det i i 833 . Måske er Gr. kommet i tanker om dette i sidste øjeblik; givet er det i hvert fald at prædikenen til denne dag (nr. 6) er planlagt og affattet sent, måske efter nr. 8.

Efter denne gennemgang af materialet føles det naturligt at inddele

15) Vandmærket, Klippan, peger afgjort på I 828 . I slutningen af 1828 brugte Gr. det jævnsides med C \& J Honig, som i løbet af i 829 helt fortrængte det, og bl. a. er enerådende i fasc. 72 III D, men et usikkert dateringskriterium. 
prædikenerne i Søndags-Bogen III i 3 rækker: Søndags- $B$ III $A$ omfattende nr. I-5, Søndags- $B$ III B nr. 6-19, og Søndags- $B$ III $C$ nr. 20-29. Af disse er $A$ og $C$ lettest at indkredse. $A$ kan med rimelighed dateres til december 1828 og evt. januar I 829 ; ved $\mathrm{nr}$. I-3 bygger vi på håndskriftmateriale, ved nr. 4 og 5 på viden om at der har eksisteret et dermed samtidigt manuskript til prædikener med dette nummer, og på deres fremtrædende bodskristendom. De er under alle omstændigheder omtrent lige gamle, det ses af deres fælles og for dem særegne slagord kirkefarvet Hedenskab (s. 86 og ı07). Til den anden side er $C$ følge af studium af »Troen og Daaben i større og mindre Cirkler«. At de udgør en særskilt gruppe, fremgår af en selvbiografisk anlagt bekendelse i nr. 20 (s. 46o f.), idet sådanne opgør med ros og dadel af forskellige faser i Gr.s fortid er en vane når han slår ind på ny veje $\mathrm{i}$ forkyndelse eller livssyn. Nr. 20 er sandsynligvis samtidig med brevet til Ingemann I9/4 I 83 I, hvor han også berører prædikenens hovedtema (GrIng s. I25). Imellem disse let afgrænsede grupper både $\mathrm{i}$ anlæg og tid - henholdsvis $\mathrm{I} 828(-29)$ og martsmaj I 83 I - ligger den heterogene gruppe $B$.

I denne yder nr. I4 og I5 det sikreste holdepunkt, idet de polemiserer mod en anmeldelse $i$ novemberheftet af Maanedsskrift for Literatur ${ }^{16}$ ) I 830 af den da udkomne ny udgave af Alterbogen; dér efterlystes den modernisering Gr. bekæmpede i Ritualstriden ${ }^{17}$ ), forældede ord og sprogformer skulle udryddes, og det uægte vers i epistlen til I. søndag efter påske, I. Joh. 5·7, måtte ikke længer tåles. Dette berørte Gr.s trosopfattelse så meget, at den angrebne episteltekst måtte udlægges i den ny samling og de lærdes trætte om treenighedsversets ægthed afvises som menigheden uvedkommende (s. 32I). Men da han nu var i gang, optog han i nr. I 5 den i Mskr påtalte »urigtige Superlativ »almægtigste« : Faderen Almagtigste (s. 34I f.), som led i en række udfald mod påstanden at liturgien var forældet. - Der er allerede givet grunde for at $\mathrm{nr}$. I 9 er skrevet efter afleveringen til trykkeriet og nr. 18 forinden, ligesom vi har omtalt det udskilte, men ikke fuldskrevne, læg fra trykmanuskriptet af $\mathrm{nr}$. I 7 numereret 102. Dettes tekst skulle være et pålideligt vidnesbyrd om Gr.s indstilling i

16) Fremefter forkortet Mskr. Anmeldelsen (bd. 4 s. 379 ff., hvad Gr. angriber s. 4 9 ff.) er usigneret, men $i$ registret $i$ bd. 20 opgives H. N. Clausen som forfatter.

17) Herom henvises til H. J. H. Glædemark: Kirkeforfatningsspørgsmaalet i Danmark indtil I874 ( 1948$)$ s. $4 \mathrm{I}$. 
februar i 83i. Udgangspunktet er som i den trykte form menigmands respekt for kirkebygningens højtidelighed: »Kirke var Bygningens Hverdags-Navn, og Guds eller Herrens Huus kun Søndags-Navnet. Dybt, christelig dybt laae Grunden til denne Tale-Brug, thi det fremmede Ord som Folket ikke forstod syndes dem ikke for godt til Muurmesteres og Tømmermænds Værk, men vore lutherske Fædre og Mødre vidste godt og følde dybt, at der vil Andet til at bygge Herren et Huus, ... « Foran det afgørende udtryk, lutherske Fødre og Mødre, der bruges adskillige gange i $C$, er udstreget christne Fadre, åbenbart et udtryk der falder Gr. i pennen men afvises, en tendens der svarer til det ovf. noterede »tilbagefald « til bodskristendommen netop i denne prædiken. Set i dette lys er det nr. 6 og nr. I2, langfredagsprædikenen med påskemorgentonerne, der virker som skrevet ganske kort før trykningen; derpå tyder også det mytologiske islæt, som de har fælles med nr. $8^{18}$ ), som vi har en redaktion af fra vinteren i8303 I, samt delvis nr. I8. Til det yngste lag i $B$ hører sandsynligvis også nr. i o, hvor Gr. skaber det ny navn Avinds-Manden for Djævelen, og nr. ı6, hvor han bruger det, ligesom igen flere gange i $C$.

Udenfor denne sammenhæng står tre af de betydeligste prædikener i $B$ : nr. 9, I I og I3. De må være ældre, snarest fra efteråret I829, idet nr. 9 virker som en udløber af Gr.s litterære sysler på den første Englandsrejse, mens nr. I I og I 3 tolker hans stemning efter hjemkomsten, hvor han 28/9 lader Ingemann forstå at det nok har været en træls sommer i London, men at det næsten føles værre at være Rede mellem Pors og Lyng, eller mellem Norges Klipper, .. « Ganske vist knytter Pors og Lyng sig til omtalen af den jyske fromhed $\mathrm{i}$ det foregående, men i Jylland kunne Gr. ikke vente andre trosvilkår hjemme igen, så hans tanker kredser om udvandring, om galt skal være til England (GrIng s. 87 f.). Udvandringstanken dukker vel tit op hos Gr., men i vor snævre periode I828-3 I kun i efteråret I829; i den relativt sent udarbejdede nr. I 7, pinseprædikenen, er den overvundet, nu er der kun tale om opgivelse af statskirken og dens kære gamle gudshuse (III s. 399 ff.). I påskedagsprædikenen (nr. I 3 ) hedder det derimod (s. 296): »var vi og vore Børn fordømte til at savne hvad vi i Vildelse har vraget, og at nøies med hvad vi i Søvne udvalgde, da vilde jeg for min Part sige Lunden Farvel, og bygge min

18) Ved Thanings omtale af nr. 6 i forbindelse med mytologien (s. 7 I), hævner det sig at han har benyttet 2. udg. ( 1860 ), hvor myterne lignes ved sindrige Hjernespind, mens de i 1 . udg. (s. I 32 ) kaldes sindrige Digtninger. 
end i København; det kunne han derimod i Nordengland, hvor landskabet ligner det jyske. Sammenligningen mellem den trange indsejling til København og suset fra det store hav i Themsmundingen (III s. 255, jf. Thaning s. 77) peger ligeledes i retning af udvé, mere på efteråret 1829 end på begyndelsen af $\mathrm{I} 83 \mathrm{I}$, og idéen om de to prædikeners tilblivelse i påsken I $8_{3}$ I må aflives som en myte.

Nr. 9, Christi Nedfart til Helvede, indtager en særstilling ved at udmale stedet for dette led i Trosbekendelsen i de allerlyseste farver, så prædikenen vel ikke ophæver men $\mathrm{i}$ høj grad fortoner den hævdvundne opfattelse af Helvede som et pinested med evig ild og tænders gnidsel, som vi møder både i nr. 3 (s. 55 og 57) og i nr. 18 (s. 423). Det er en tillidsfuld fremstilling af de henfarne vantros lejlighed til omvendelse ved mødet med Kristi strålende guddom, som Gr. har fundet hjemlet hos Kirkefædrene (jf. især s. 2 I 4). Vi ledes derved hen til studier han var kommet i gang med på British Museum og havde fortsat herhjemme, og som vi kan følge i hans litterære udtogsprotokol fra Englandsrejserne, fasc. $3^{2} 7^{19}$ ). Rygraden i hans litterære sysler den første sommer var Thomas Wartons History of English Poetry i Richard Prices nyudgivelse I824, der gav ham et indblik i den middelengelske og nærmest følgende litteratur, og hvorfra han bl. a. gjorde et notat (s. I5) om digtninge om nedfarten og deres kilde, Nicodemus' evangelium ${ }^{20}$ ). Tilsyneladende er de sidste indførsler fra denne sommer et kort udtog (s. 43 samt nogle linjer på den næsten ubeskrevne $4^{2}$ ) af John Pearson: An Exposition of the Creed (4th ed., $\left.{ }_{1} 676\right)$; forfatteren var en berømt engelsk teolog, uden indflydelse $\mathrm{i}$ Cromwells tid p. g. a. katoliserende tendens, men udnævnt til biskop under Karl 2. Skønt hans synspunkter faldt så meget sammen med

19) I en tidligere redegørelse, Orbis Litterarum V (1947) s. 269 ff., gik jeg desværre ud fra, at alt i fasc. 327 der berører Gr.s engelske sysler, stammer fra arbejdet i London 1829, men dette må indskrænkes til at gælde s. I-43. De følgende udskrifter af kirkefædre (s. 44-59) er formentlig foretaget i København i vinteren 1829-30, mens listen over de Thorkelinske hdskr. på det Kgl. Bibliotek (s. 75-78) og udskrifterne af Dudo om dansk oldhistorie (s. 8o) må tilhøre vinteren 1830-31, hvor Gr. også har anlagt den første del af registret på første side, til og med Dudo. Det efterfølgende er da fra den tredje rejse, men de få mellemliggende sider fra opholdet 1830 , hvor Gr. kun arbejdede lidt på British Museum. Der er her to hovedstykker: udskrifter af Washington Irving: History of the Life and Voyages of Christopher Columbus, kilden til Gr.s Columbus-digt, vel fra 1830, og af Byron, jf. note 22.

${ }^{20}$ ) Referat og karakteristik Tue Gad: Legenden $i$ dansk middelalder ( $196 \mathrm{I}$ ) s. $103 \mathrm{ff}$. 
Gr.s at Henning Høirup ${ }^{21}$ ) har kunnet bruge et af citaterne som udtryk for Gr.s teologi efter I 825, stødte han denne ved at hævde at nedfarten til dødsriget var en senere tilføjelse til Trosbekendelsen ( $\mathrm{s}$. 225 f.), så Gr., formentlig efter hjemkomsten, kastede sig ud i studier af Cyprianus (Opera, Paris I 726 ) m. fl., bl. a. over dette spørgsmål, som han gjorde anmærkninger til. Søndags-B III nr. 9 må være en direkte følge heraf, men også nr. I 3 kan have nogle af sine forudsætninger her. Gr.s teologiske udvikling henimod nybruddet $183_{2}$ beskriver altså ikke en lige linje, men en kurve: hans lutherdom er blevet svækket under studierne I 829, men styrket i i 83 I.

Til Gr.s gøremål i vinteren I830-3 I bør da kun 2 I af de 29 prædikener i Søndags-B III regnes: nr. 6-8, I o, I 2 og I 4-I 8 fra tiden omkring årsskiftet, nr. I 9 fra slutningen af februar eller begyndelsen af marts, og nr. 20-29 fra forårsmånederne. Dertil kommer den omtalte store teologiske artikel og Gr.s anmeldelse af Mynsters nyudkomne Begrebet af Dogmatik, der udmærker sig ved en behageligt afdæmpet tone $\mathrm{i}$ sammenligning med hans forudgående teologiske indlæg. Men han havde jo også andre jern i ilden, først og fremmest studier med henblik på den store udgave af angelsaksisk litteratur han gerne skulle over at tilrettelægge, selv om han først hen i maj fik vished for at rejsen kunne gennemføres; et vidnesbyrd herom er hans liste over de Thorkelinske håndskrifter vedrørende engelsk på det Kgl. Bibliotek (fasc. 327 s. 75-78). Endvidere havde Julirevolutionen og andre aktuelle spørgsmål, samt hans egen afhængighedsfølelse under censuren, i efteråret fremkaldt hans skrift Politiske Betragtninger med Blik paa Danmark og Holsten, og endelig gav den danske bogverden og et skred $\mathrm{i}$ hans egen litterære holdning ham et og andet at tænke på.

Han var kommet hjem fra den anden Englandsrejse med et helt uventet udbytte: han var blevet bjergtaget af Byrons poesi. Det er atter fasc. 327 vi ved det fra: 6 siders udskrifter af Byrons mindre digte (s. 69-74), delvis af erotisk indhold ${ }^{22}$ ), men f. eks. også to linjer der kan have medvirket til hans brud med bodskristendommen: he that acts as wise men ought, / But lives, as saints have died, a martyr. Formodningen om en heftig forelskelse på den anden Englandsrejse, der senest er hævdet som et af Thanings hovedsynspunk-

21) Grundtvigs Syn paa Tro og Erkendelse (1 949 ) s. 389.

22) På de første 5 sider findes The Destruction of Sennacherib, Ode to Napoleon Bonaparte (versionen med 16 strofer), udtog af Monody on the Death of Sheridan, en linje fra begyndelsen af Manfred (The Tree of Knowledge is 
ter, er altså en realitet, og det må være hans hjerter dame ${ }^{23}$ ), som han måtte renoncere på varig forbindelse med, der har åbnet hans øjne for det værdifulde i Byrons poesi. Fordybelsen i den må være sket på British Museum, han ejede to af Byrons værker, men ikke det bind (Works Vol. 3, i 8 i 9 eller en hvilkensomhelst af de mange omtrent ens udgaver fra samtiden) de udskrevne smådigte stammer fra.

Af den hjemlige digtning blev Gr. i vinterens løb tvunget til at tage stilling til to værker der ikke var efter hans hoved: Henrik Hertz' da endnu anonyme Gjenganger-Breve, der udkom juleaften I $83^{\circ}$, og Ingemanns Huldre-Gaverne, som hans ven i Sorø sendte ham i påsken I 83 I. Det sidste værk læste Gr. pligtskyldigst straks efter modtagelsen, men Gjenganger-Breve trak han det ud med til han havde hørt så meget om dette sensationsværk at han måtte have syn for sagn. Den første virkning var en lige så eksplosiv som taktløs hentydning som led i en protest mod forbøn for de døde i et brev til Busck, der nylig havde mistet sin lille datter og efter Gr.s mening drev dødekultus med hende (GBusck s. I06): »Det er kun i Gienganger-Historierne at Ligene staae op og kyse dem, der har en ond Samvittighed, og skiøndt det er Noget, der i Litteraturen skeer hveranden Dag, saa er der dog Noget, Christne Folk maae aldrig befatte dem med, men naar de fristes dertil, slaae Kors for sig, ...« Men en uge senere kunne han i et brev til Ingemann (GrIng s. I I4) hæve sig ironisk over emnet og, uden at give slip på fortørnelsen over afguderi med de døde, fremhæve hvor langt den anonyme digter stod under sit forbillede Baggesen; nu var han mest vred på de åndløse københavnere, der havde

not that of Life), samt afsnit af forskellige af digtene i Hebrew Melodies. Disse fortsættes på s. 74 (gengivet her i facsimile) med Thy days are done str. 3 lin. $\mathrm{I}-4$, 》All is vanity, saith the Preacher «str. 3 begge halvstrofer, og hele Sun of the Sleepless. De sidste 6 udtog stammer fra spredte digte: Stanzas written in passing the Ambracian Gulf 2 sidste linjer; The spell is broke, the charm is flown (Written at Athens) 2 sidste linjer, citeret oppe i teksten; sidste strofe af Written beneath a Picture - den første lyder: Dear object of defeated care! / Though now of Love and thee bereft, / To reconcile me with despair, / Thine image and my tears are left; Inscription on the Monument of a Newfoundland Dog lin. 5-6; ottendesidste og syvendesidste linje af A Sketch; samt sidste halvstrofe af Stanzas to [Augusta], hvis første strofe begynder: Though the day of my destiny's over, og slutter: And the love which my spirit hath painted, / It never hath found but in thee (ordet thee udhævet af Byron - som i alle digtets strofer, også den af Gr. citerede).

${ }^{23}$ ) Snarest Mrs. Bolton, som Gr. traf eneste gang $i$ et selskab 24/6 1830 (jf. Thaning passim), men eventuelt den ene af John Bowrings søstre, jf. Gr.s digt til hende, Liljevaand $i$ Vesterled (Poetiske Skrifter V s. 497 ff.), og GrIng s. 93 . 
ladet sig rive med. I samme ånd, og sikkert fra anden halvdel af januar, er hans rimbrevsfragment Til Baggesens Aand (fasc. 388 nr. I 30, trykt Poet. Skr. V s. 499 f.). I $3^{8}$ linjer, hvoraf de første træffer Baggesens skødesløst elegante stil fint, har Gr. nået at snerte den franske lethed overfor livets alvorligste spørgsmål, og den københavnske pjattethed og sensationstrang, der her var blevet fænget endnu mere end af Heibergs Kjobenhavns flyvende Post ${ }^{24}$ ). Han er ikke længer kristeligt forarget, men han er fornærmet på Baggesens og hans endnu levende fællers vegne over at man har turdet bringe noget sådant til torvs i den store afdøde digters navn. Det er skjalden Grundtvig, ikke præsten, der taler.

Hvad Gr. havde at udsætte på Huldre-Gaverne, ved vi kun delvis, for hans kommenterende takkebrev er tabt, sandsynligvis tilintetgjort af Ingemann; men noget kan vi slutte af Ingemanns svar 7/4 og Gr.s gensvar $9 / 4$ (GrIng s. I I 7 ff.). I det første står bl. a.: »At du af de to Hovedfejl ved de fleste Bøger $\mathrm{i}$ vor Tid kun finder den mindste og tilgiveligste ved »Huldregaverne«, var mig meget kjært. ... Bogens Mangel paa verdslig Tilværelse erkjender jeg fuldkommen; ...« Dette sidste er sandsynligvis »den mindste og tilgiveligste« af fejlene ved tidens litteratur; hvis man tør gætte på den største af fejlene, som Ingemann klarede frisag overfor, kunne det være mangel på ånd. Men at Gr. har sagt vennen andre ubehageligheder, fremgår allerede af at han så omgående trak i land, som det var hans vane når han fortrød en for skarp tilrettevisning af en ven, eller frygtede at den blev misforstået; dette ses i korrespondancen med Busck, der ikke var så ømtålig som Ingemann, men også gemte breve der viste Gr.s umiddelbare reaktion. I det bevarede udglattende brev gør Gr. afbigt for at han har påtalt eventyrformen, og tager brodden af sin karakteristik af bogen »som trykt Manuskript for Venner« ved at indrømme det berettigede i Ingemanns polemik. Men når han spår ham at han nok slipper for videre tiltale, efter at han har slået fra sig, virker det som ønsketænkning. Kløften mellem Ingemann og Molbech, der var karikeret i Huldre-Gaverne som kvittering for sin bidske anmeldelse i Mskr 2 af Erik Menveds Barndom ${ }^{25}$ ), har Gr. nødig set uddybet,

24) Jf. Morten Borup: Fohan Ludvig Heiberg II (1948) s. 93 ff. Forøvrigt havde Gr. selv været begunstiget af denne sensationslyst da han udgav Kirkens Gienmale, jf. J. P. Mynster: Meddelelser om mit Levned (1 854) s. 223.

${ }^{25}$ ) Jf. Vilhelm Andersens overblik over situationen omkring Huldre-Gaverne, Illustreret dansk Litteraturhistorie III (1924) s. 240 f., og Morten Borups 
efter at han selv havde sluttet fred med Molbech og i London nydt godt af en introduktionsskrivelse fra ham.

Hvis man ser bort fra at Huldre-Gaverne er et nødsskrig, og læser den for dens egen skyld, fornemmer man et pust af noget i dansk litteratur usædvanligt, en etik forklædt i eventyrets form. Mellem den konventionelle forløjethed i en verden der vil bedrages, og den tidløse kabbalistisk inspirerede erkendelse, repræsenteret ved den gamle greve og hans datter, står den entusiastiske stud. theol. Ole Navnløs, der gennem et bugtet livsløb, både før og efter et ophold hos greven med en brat ende da han findes uværdig til at indvies i de dybe hemmeligheder, befæstes $\mathrm{i}$ at skønheden findes hvor vi selv vil se den. Når han i første omgang standses i sin udvikling mod den højere erkendelse, skyldes det at han er begyndt på et farligt grundlag: hans klarsyn er ikke af himmelsk men dæmonisk oprindelse. Det er fremkaldt af en øjensalve, den bedste af de to huldregaver han har arvet efter sin sindssyge mor; den anden er tre diamantringe der får deres bærer til at tage sig ud i verdens øjne, og Ole fører et tomt nydelsesliv fra han tager dem i brug til de stjæles fra ham. Ringenes magiske virkning er altså kun skadelig, men øjensalven har en relativ værdi ved at åbne øjnene for verdens falske bedømmelse af godt og ondt, kønt og stygt. For Ingemann er den blevet et redskab til at afsløre megen lumpenhed i det litterære og akademiske liv, uden at det ædle klarsyn eller den højere stræben er profaneret. Bortset fra karikaturen af Molbech går det hårdest ud over universitetet, hvor Oles gammellutherske fromhed tørner mod den herskende retning midt under teologisk embedseksamen, så han dumper og bagefter bliver relegeret, og hvor en halt udenlandsk teolog, hvis hestefod og dyrehale kun Ole kan se, både ved den fatale eksamen og tidligere under en disputats fremmer skepticisme og beundres for sin formalistiske begavelse. Kritikken kulminerer i en rapport fra den fremmede lærde, dr. Stagefyr, til hans »overguddommelige Herre og Mester«, Djævelen (s. I 22 ff., strøget i senere udgaver), om hans sags fremgang i København. Her gør Ingemann front mod snobberiet for alt udenlandsk, naturfilosofi og hegelianisme, studenternes åndshovmod, Mskr.s redaktion, samt poesi i det ondes tjeneste, rimeligvis med adresse til Gjenganger-Breve ( $\mathrm{s}$.

redegørelse for forhistorien, Christian Molbech (1954) s. $263 \mathrm{ff}$. Her skal tilføjes, at Ingemann i undertitlen på Opstanden $i$ Litteraturstaden, »Trykt som Manuskript for Fjender «, parodierer Gr.s karakteristik af Huldre-Gaverne, jf. GrIng. s. 128. 
I 32 ) : »Eet eneste ret infernalsk Digt med Liv og Aand virker mere til vort Riges Udbredelse, end hundrede philosophiske Smagssystemer og al død aandløs Snak mod den Konst og Poesie, vi maae bestride.«

Det positive i Huldre-Gaverne lå over Gr.s fatteevne, det var Sibbern den eneste i samtiden der begreb; men heller ikke i det negative, den skånselsløse karikatur af samtiden, har Gr. kunnet følge vennen. De stod for det meste last og brast, men netop i disse år var Gr. ikke udelt tilfreds med Ingemanns forfatterskab; han undte ham nok de historiske romaners folkelige succes, men brød sig ikke selv meget om $\left.\operatorname{dem}^{26}\right)$. I deres syn på den øvrige danske litteratur var der tilsvarende divergenser. Ingen af dem havde noget tilovers for Heiberg; men den der senest havde prøvet at dæmme op mod hans indflydelse, Hauch, som var Ingemanns ven og kollega i Sorø, kunne det aldrig falde Gr. ind at gøre fælles sag med, selv om de måtte harmes lige meget over slagordet »Med fransk Respect for Love« (Gjenganger-Breve s. 4I, udhævelsen Hertz'). Hovedformålet med Gjenganger-Breve, at sætte Hauch på plads mens hans sidste ord endnu var det forfejlede angreb på »Vaudevillemesteren«, Den babyloniske Taarnbygning $i$ Mignature ( $183^{\circ}$ ), har ladt Gr. uberørt, hvis han overhovedet har ænset den hjemlige polemik under sit personlige mismod den foregående vinter. Endelig har Gr. ikke delt det af Ingemanns kritik der faldt tilbage på Baggesen (GrIng s. I I I ) : »det er en næsten skuffende Efterligning ikke alene af Baggesens Rimbrev-Stil, men af hans Synsmaade paa hans laveste Standpunkt som det I 8de Aarhundredes sidste Kunstrepræsentant hos os, naar han som Sprogets Ridder satte Formen, selv i lavest Betydning, over Ideen.« I Gr.s øjne bestod værkets helligbrøde, litterært set, $i$ at Baggesens navn var blevet misbrugt $i$ et nymodens makværk. Til gengæld havde Ingemann, som i den foregående tid havde fulgt regelmæssigt med i den litteratur der danner baggrund for Gjenganger-Breve, en helt anderledes klar forståelse af hvad den anonyme digtkreds sagde om den aktuelle litterære situation og dens sandsynlige videreudvikling (jf. de følgende betragtninger i brevet, GrIng S. I I 2).

For Gr., der nu i mange år var gået sine egne veje og ikke siden

${ }^{26}$ ) Jf. GrIng s. 100 og Kjeld Galster: Ingemanns historiske Romaner og Digte (1922) s. 93 f. og 107. Morsomt nok nærede Gr.s modpol på denne tid, H. N. Clausen, som Ingemann heller ikke kunne lide, større sympati for de historiske romaner, og ærgrede sig over Molbechs anmeldelse af Erik Menveds Barndom, jf. Optegnelser om mit Levneds og min Tids Historie (1877) s. I $54 \mathrm{f}$. 
Tylvtestriden og det ubehagelige mellemværende i i 8 7 med Heiberg havde engageret sig i den litterære debat, stod de år hvor de yngre forfattere havde taget føringen som en stilstandsperiode. Grænsen for den gode gamle tid var I $_{1} 4$, året for Heibergs - og Hauchs - debut (GrIng s. Io I f., udhævelsen Gr.s): »naar vi sammenligne Udsigterne i Læseverdenen for og efter I8I4, da maa vi vel dømme, at $\mathrm{i}$ det mindste den Slags Ro og Mag, vi siden har haft, ikke er Litteraturen synderlig tjenlig. Det synes mig overalt, at Verden paa sine gamle Dage slet ikke kan have Fred, uden at falde i Søvn og drømme om lutter Gaaselevere og Skildpadder og Tærskemaskiner og polytekniske Skoler $^{27}$ ), hvad der giver Samtalerne med den en dræbende Kjedsommelighed.« Som han tidligere havde ønsket at stå som den formidlende skikkelse $i$ et triumvirat med Baggesen og Oehlenschläger som de to andre deltagere ${ }^{28}$ ), så han sig i I83 I som midtpunktet $\mathrm{i}$ et nyt, hvor Ingemann indtog den tredje plads, en ønsketænkning med udgangspunkt $i$ en situation hinsides $\left.1814^{29}\right)$. Noget $i$ den retning må der have stået i det tabte brev om Huldre-Gaverne, idet Gr.s ny positive holdning til Oehlenschläger er et fremtræedende emne i den videre korrespondance (GrIng s. I i 8-24). Det har såret Ingemann, for hvem hvert værk af Oehlenschläger var et nyt tegn på åndløshed, at Gr. netop kom ind på ham i sin private anmeldelse af det dybt tænkte angreb på tidens forløjethed, og Gr. måtte da også i sit udglattende brev indrømme, at tilnærmelsen foreløbig var mere privat end åndelig.

Oehlenschläger var sluppet for tiltale i Gjenganger-Breve, men in-

${ }^{27}$ ) Den polytekniske Læreanstalt (nu Danmarks tekniske Højskole) var oprettet efter kgl. reskript af 27/1 I829 og indviet 5/ I I 1829, dens første direktør var H. C. Ørsted, jf. iøvrigt Traps Danmark 5 II (1959-6o) s. 284. At Gr. ellers nu havde mere sans for teknikken, ses i Søndags-B III nr. I4 (s. 327): Vi veed det jo, Venner! at naar vi have seet en konstig Indretning, hvorved vi gjordes opmærksomme paa Drive-Hjulene, og paa den kiendelige Sammenhæng mellem Aarsag og Virkning, da kan vi vel derved, skiøndt uindviede i Konstens Hemmeligheder, faae en langt klarere Forestilling om Værket, end vi hidtil havde, men at vilde vi nu deraf forklare Grunden til det Hele i Konstnerens Sjæl, og Reglerne han fulgde, da gjorde vi os kun til Latter for de Kyndige, og misledte dem, der var troskyldige nok til at stole paa vort Ord.

28) Jf. Gustav Albeck: Omkring Grundtvigs Digtsamlinger (1955) s. 39 f.

$\left.{ }^{20}\right)$ Jf. bemærkningen Skribenten Nik. Fred. Sev. Grundtvigs Literaire Testamente $\left(1_{127}\right)$ s. Io om at hvis de tre havde stået sammen, 》saa maatte vore Skjalde-Penne, der i Grunden gjøre Eet, dog finde deres Over-Mænd i Nordens Læse-Verden, før det kunne seire, som de bøde Spidsen!« 
gen var i tvivl om at angrebet på Hauch, hans mest trofaste tilhænger, sigtede videre mod ham, der tre år før netop var blevet dadlet af »Vaudevillemesteren « for manglende »Respect for Love«. Hans stilling var $\mathrm{i}$ virkeligheden svag, han savnede kontakt med sine samtidige, og han var ikke mindre ivrig efter en tilnærmelse end Gr. Det første skridt havde været en samtale på gaden $28 / 9$ I $829^{30}$ ) efter I 7 års tavshed (jf. Thaning s. 263), og det var nu fulgt op af en privat invitation, uden at samværet dog havde givet løfter om en fælles litterær stræben. Men kontakten var etableret; og Oehlenschläger, der endnu I 829 havde omtalt Gr. vrangvilligt i en tysk selvbiografi ${ }^{31}$ ), viste sin taknemlighed i den danske bearbejdelse (Levnet II (marts) I 83 I, s. 292 f.), på en måde Gr. ikke kunne stå for:

Grundtvig gik snart en ganske modsat Vei. - Det var ikke længer Thors Hammer, han beundrede; det var ikke Christendommen saaledes som jeg følte den, der tilfredsstillede ham. Mine Anskuelser bleve ham meer og meer imod, og vi bleve fremmede for hinanden. Ligesom han før havde sat Poesiens høieste Værd i at fremstille Historien tro, saa havde den siden blot Værd for ham i Religionens Tieneste. Da jeg nu vedblev at mene, at Poesie har sin selvstændige Værd, i Digtningernes Skiønhed og Sandhed, og hverken i et blot objectivt Stof, eller subjectiv Tro, saa var det naturligt, at han og hans Tilhængere entidlang betragtede mine Værker som et »Spil med det Aandelige«; hvilket de ogsaa vare, naar man tager Ordet $i$ en ædel Betydning; det vil sige: en fri Forestilling i Phantasien, ledet af Vid, Følelse og Fornuft. Derfor siger man jo ogsaa: et Sørgespil. Grundtvig yttrede sit Mishag mod mig, som mod utallige Andre; men vedblev dog altid at have personlig Godhed for mig; og i senere Aar har han atter venligt og ædelt nærmet sig mig.

Her havde Gr. fået det håndslag han havde savnet under deres sidste samvær. Der var givet klar besked om hvilket grundlag de kunne mødes på, og ved at tilkendegive sin respekt for historien som poetisk kilde havde Oehlenschläger anvist et synspunkt for bedømmelsen også af hans eget forfatterskab; og selv om Gr. rent sagligt anså hans »fri Forestilling « for lovlig fri, i al fald når det gjaldt de nordiske myter ${ }^{32}$ ), vidner definitionen af et sørgespil om en alvorlig hensigt. Samtidig kan det fremdragne fortrin ved den poesi Gr. havde

30) Samme dag som Gr. skrev - eller havde skrevet - sit vemodige brev til Ingemann med udvandringstankerne, jf. ovf. s. I 9 .

31) Trykt som indledning til hans første samlede udgave på tysk, Schriften.

32) Jf. f. eks. anmeldelsen af Baldur hin Gode i Ny Minerva dec. 1807, og fortaleudkastet i fasc. 251 (1823) til en påtænkt ny udgave af mytologien. 
sluppet ved udgangen af i 8 io, være kommet som en tilskyndelse i det psykologiske øjeblik til igen at slå ind på en vej han og Oehlenschläger begge fandt tjenlig for nationallitteraturen. Den oprindelige plan om en revideret udgave af Nordens Mytologi i 808 kan godt have en af rødderne her.

Dertil kommer så Ingemanns situation i i 83 I, som Gr. fulgte som tilskuer på nærmeste hold. Huldre-Gaverne var et endnu mere ubalanceret svar til Molbech, end hans egen Krønikens Gienmale havde været; og efterspillet blev et opgør med H. C. Ørsted, der ikke gav hans eget i I8I4-I 5 noget efter. Mens Gr. var i England for tredje gang, med en anbefalingsskrivelse fra Ørsted til en professor i Cambridge, rykkede denne i Mskr i videnskabens navn ud mod HuldreGaverne, som et udtryk for $\gg$ det Fornufthad og den Haan mod Videnskab, der har bemægtiget sig et vist Partie« (Mskr 6 s. I3). Skønt anmeldelsen var anonym, vidste Ingemann hvem den skyldtes, og meddelte $7 / 9 \mathrm{Gr}$. at han havde udsendt et »Svar til »den lille Anklager« i Maanedsskriftet«, men hverken dette eller sit sidste indlæg sendte han Gr. (GrIng s. I 27 f. og I33), der næppe heller savnede dem. Tværtimod må det have været rystende for ham at overvære, hvor vidt den sagtmodige Ingemann kunne drives i en kamp mod videnskaben for religionens sag, ikke mindst når den led for led lignede hans egen gamle kamp.

Derfor må den hjemlige litterære situations medvirkning ved Gr.s omsindelse, der når sin fulde afklaring i 1832 , ikke undervurderes. Det er i i 83 1 han har trukket grænsen overfor Ingemann, så han kunne bevare sit genvundne venskab med Molbech og det korrekte forhold til H. C. Ørsted; og det er fra påsketid samme år han og Oehlenschläger er så vidt på bølgelængde som de nu engang kunne komme. Vi kan endda se (GBusck s. I i 7 ff. og I 32 f.), at havde det stået til Gr., var også han og Mynster blevet udsonet i foråret I 83 I.

Selv om den litterære manifestation af tendensen »Menneske først - « ventede til 1832 , var dens forudsætning i Gr. selv til stede da han tiltrådte den tredje Englandsrejse. $\mathrm{Og}$ allerede da stod han for sin egen generation med det ansigt han bevarede resten af livet. 
Arigron's Worker V.iil This nume, our - harging Rosts alony, This folel the theme of Thorue sony Fivor vingin vorier pourd!!

The sepent of the fied, bis ant Alul speles, is woun from harming. thut that whith cirte around the heart, Ol! who hath jower-of'charming?

It wice not list to wisclom's Pure, Nor mussicus a voice can lure it thit heie itstising your evermire The soul thut milit enche it.

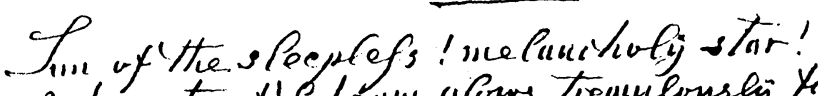

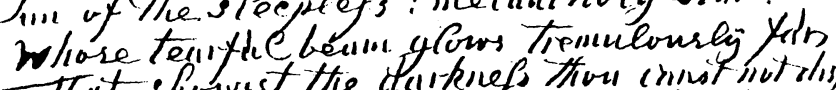

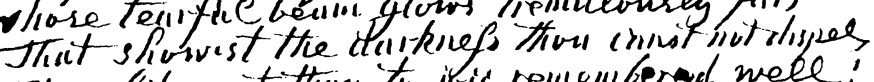
How like nit thin it jois remculbered weel!

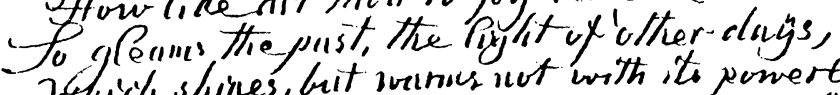
Which shines, bit wornus not with its pimerass A niglit-benum Sorrow ivatitikes to be hooll, rnijs; Distivit, but clistanta-rear-but, ul fiomival!

I innut Pose a vontil Yor- thee trit wonel not lose the Yis a world.

- Re that nits as wive men ounght,

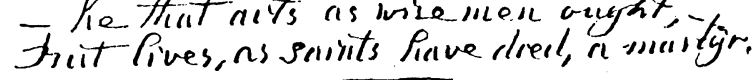

- Jis said witt Sonvw Jime inn clype. trit tilus If fee c'mm never be Irice:

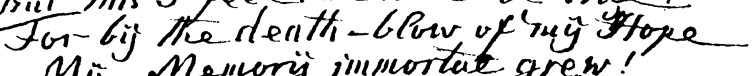
Mij Memorÿ immortat grew!

When aee is done, syiun the tomb is seen,

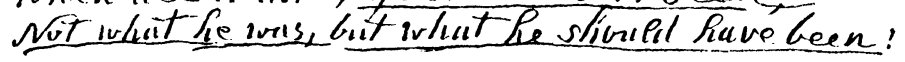

Down to the dist! - and in thine rottist awaig, Even worms shale pen'sh oni thij poisonions "lagy.

Int The desert a yinturtain is springing,

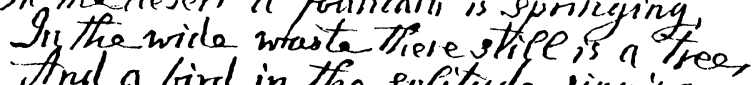
And a bird in the sulitule singing, which speaks to injuspirit of thee

Sidste side af Grundtvigs Byron-indførsler på British Museum ı 830, i Grundtvigarkiv fasc. $327,2^{\circ}, \mathrm{Kgl}$. Bibliotek, lidt formindsket gengivelse. Redegørelse for indholdet findes side $21-22$, note 22 . 